\title{
Stories, Places: Storied Place and Placed Story
}

"... the universe is not simply a place but a story-a story in which we are immersed, to which we belong, and out of which we arose."- Brian Swimme \& Mary Evelyn Tucker

\section{Introduction}

According to storyteller and medical sociologist Arthur Frank stories "enact realities: they bring into being what was not there before" (Frank 2010, 75); they become lives, the lives of places and all that inhabits those places, capable of constituting conditions for either enriching or diminishing those lives. By inflicting themselves on places, their inhabitants, stories can limit or liberate them "according to whatever imagination the stories make available" (Frank 2012, 49): subject, object, subaltern, elite-all can be created, positioned, and "revision[ed]" (Richardson 1997, 299) by the story told. The story of terra nullius, for example, created and propagated by the settler colonizers and colonials of Australia by storifying matter as commodity there for the taking, uninhabited and ownerless as the story goes, enacted a reality of dispossession and established a hegemony of white Anglo male with all else 'othered', their stories pathologized, colonized.

However the reverse is also true: realities can enact stories, stories that when not silenced allow the 'other' to be heard, to be seen. These are stories that make visible (and compelling) the invisible-the links between place and inhabitant (Grvenewald 2003). Yet to decolonialize' a story, reconfigure the story as one where subaltern has the potential to become a part of the subject (Barad 2007) with agency, within the context of the story told, can be (as in the case of Australia) a "narrative struggle" (Collins-Gearing and Osland 2010, para. 10) for the 'othered'. For place that had once been hospitable to its inhabitants-home-has been rendered inhospitable by the colonizers' stories, limiting 'others' to the margins of colonial life: liminal spaces-"a borderland . . . a vague and undetermined place created by the emotional residue of an unnatural boundary" (Anzaldúa,1987, 3)-where imaginary resources with which to contest those myths of colonization are scarce (Fricker 2007), if existent at all.

\footnotetext{
1 Coloniality as Nelson Maldonado-Torres $(2007,243)$ says is different from colonialism and requires a different praxis referring as it does "to long-standing patterns of power that emerged as a result of colonialism, but that define culture, labor, intersubjective relations, and knowledge production well beyond the strict limits of colonial administrations. Thus, coloniality survives colonialism. It is maintained alive in books, in the criteria for academic performance, in cultural patterns, in common sense, in the self-image of people, in aspirations of self, and so many other aspects of our modern experience. In a way, as modern subjects we breathe coloniality all the time and every day." The "de-' in decoloniality therefore "indicates above all the need and the goal of the re-: epistemic reconstitutions, re-emergence, resurgence, re-existence. That is, neither new nor post" (Mignolo 2017, 5-6).
} 
Yet the power of stories lies in their capacity to "become true as they are told" (Frank $2010,49)$. For "the core truth" about stories is "not correspondence but performance" (Frank 2010, 41; see also Slaby, Mühlhoff and Wüschner 2017) and their very ability to balance multiple truths at one and the same time (Frank 2010). This is what lies at the heart of any story. Stories can thus provide a different way of knowing and a way of knowing differently (St Pierre 1997, 177), a way of contesting and decolonializing those stories, the discourses and practices, within places and spaces where the myths of Western colonization live and breathe, replicate and reproduce: schools and universities.

For a while now I have been "wondering" (MacLure 2013, 228) about, pondering this link between story and place, inhabitant and colonizer: the inextricable and intractable connections that come into being between them. And so in this brief diffractive piece where a constellation of concepts such as space, place, story, performance, hospitality, refrain, vibe, power to/power over, rhizomes, come together with 'truth' emanating from their entanglement, I hope to explore those connections and provide some compelling examples of story as place and place as story with particular reference to one particular place, a school', and the inhabitants of that particular school in Cape Town, South Africa. For in schools where matter, in all its forms, is "storied" (lovino and Oppermann 2014, 12)-has its own story to tell-and storified, stories matter.

The school as storied and storified place

Everything in a school has stories to tell: not all will be legible, easy to translate (if at all), but many will provide compelling, "vivid", articulate, powerful and moving (Cohen 2015, 275) tales of "co-existence, interdependence . . extinctions and survivals" (lovino and Oppermann 2014, 14). From the graffiti or lack thereof on desks and walls, hallways and restrooms, to those liminal places and spaces of doorways and doors, all 'tell tales' of inclusion and exclusion: nonlinguistic performativity in search of an active, willing listenera home. So what stories does a school housed in buildings that date back to the Cape Town era of the late 1700s have to tell, buildings constructed by the Dutch and lived in with their families; buildings that have known many owners over a significant number of years, have witnessed enormous change take place-ecological, geopolitical and sociocultural-in this tiny south-western corner of the African continent? What stories do these walls and bricks, soil and grass communicate? What did/do those doors keep in, keep out, include, exclude; what difference did/do they allow to "connect", merge for "the sake of exchange" (Rose 2002, 314)? How does school as storied and storified place interpolate and interpellate inhabitants and inhabitants place? In the sections that follow I use the notion of hospitality both in Derridean sense of "absolute hospitality" (Derrida and Dufourmantelle 2000, 25; see also Derrida 2005, 6) and also in the way it is practiced locally as practical philosophy and philosophical practice by matter as text and text as matter (Barad 2007; see also lovino and Oppermann 2014), as well as the Deleuze and Guattari (1987) notion of the 'refrain' to explore the questions raised above.

\footnotetext{
2 I chose this particular school as the focus of my meditations as it is emblematic in its totality of how coloniality reterritorializes: with its very name, its storied colonial buildings, its colonial language of instruction, its Eurocentric curriculum, uniforms, customs and rituals, all pointing to the fact that epistemic reconstitutions, re-emergence, resurgence, re-existence are far from being embedded in the African context. The specific name of the school is not mentioned to ensure that the ethical rights of others are not infringed or violated.
} 
The hospitable and inhospitable

The notion of hospitality and how it is practiced locally in South Africa differs from how it is practiced in the West according to Deumert and Mabandla (2017) in one major respect: unconditionality (Derrida and Dufourmantelle 2000; Derrida 2005)-that which is beyond duty or rights. The West with its middle-class urbanized Christian values retains the Kantian trace of tolerance, a socially held affect, posited by Kant in his Third Article of Perpetual Peace (1795), where the 'stranger' remains on the threshold-physically and metaphorically-made aware, corporeally and affectively rather than by word of mouth and/or written, that they are tolerated, virtually unwelcome 'guests' for whom the consequences of deviating from the behavioural norms required of the 'guest' can be dire. So too in South African Black urbanized upper and middle-class populations (Deumert and Mabandla 2017). Yet in South Africa those positioned as poor, working class exhibit a different praxis altogether (Deumert and Mabandla 2017): that of "absolute hospitality" (Derrida and Dufourmantelle 2000, 25) where the 'stranger' is not seen as 'other' at all but rather different yet unconditionally welcome and welcomed (Deumert and Mabandla 2017): a stranger within (Derrida 1998, 2003; see also Anzaldúa 1987; as well as Ahmed 2000) with stories to tell.

However, it is not just inhabitants that make place hospitable to some inhospitable to 'others'; storied and storified place creates boundaries, a "vibe" (Deumert and Mabandla 2017, 404), that can at one and the same time be welcoming and exclusionary, inclusive and exclusive, tentative, tolerant, curious, judgmental, and absolute. The "vibe" at this particular school is one of white Anglo male where 'otherness' at the superficial level of skin colour and sex is tolerated as long as the caveat of 'essence', that which is considered essential to belonging, is 'rght'. That English is taught as the home language points to what that essence might comprise. This is a school that is named after the English patron saint of crusades-slaying all that is strange, a stranger: not white, not Western-and presents itself as a (English) Grammar school, down to the very English school uniforms that can both constrain and liberate by the sense of 'belonging' it promotes or denies. So too the curriculum that offers only a patronizing nod to its "situated[ness]" (Haraway 1988, 581; see also Spry 2001, 710) in the African context and continent with its inclusion of Afrikaans and isiXhosa as languages additional to the English taught, a compulsory 'home' language despite students coming from many different linguistic backgrounds and home languages. The "vibe" (Deumert and Mabandla 2017, 404) as such is not just a personal corporeal presence but one that flows between inhabitants, a materiality of feeling that "sticks" (Ahmed 2004, 100) with students storified to the 'norm', the English grammar school norm where the historical experience of apartheid interpolates and interpellates them as nothing other than the stranger within, "strangers to [them] selves" (Kristeva 1991). This is a system that despite its political demise has managed to reconfigure itself, to "reterritorialize" (Deleuze and Guattari 1987) what was there before.

As such the Deleuze and Guattari geo-philosophical notion of the "refrain" (Plateau 11 1837: Of the Refrain) is relevant here as the refrain of schools past-English grammar schools-has taken flight to land anew from whence it departed. The refrain, habits as much individual as they are social and cultural (Janz 2001) and material, is the stories 
matter tells and retells that show us for what we are, leads us down different paths yet to the same ontology of story as something always a part of matter, that protects as it ventures out along "'lines of drift"” (Deleuze and Guattari 1987, 312) with their "different loops, knots, speeds, movements, gestures, and sonorities" (p. 312): features that draw the listener in as does the refrain from any popular melody that we hum along with without realizing, and which when not fixed-not striated and striating, not sedimented and sedimenting-allows the body to deterritorialize. This is refrain as ontology, an ontology:

that provides tools to describe transformative, creative forces and movements... it presents a world understood as a complex of interconnected assemblages (earth, territory, forms of deterritorialization and reterritorialization), where the overriding norm is that of deterritorialization. (Patton 2000, 9)

However the refrain is as much a part of "horror stories" as it is of "fairy tales" (Deleuze and Guattari 1987, 312), positioning storyteller, whatever its form, as victim, or agent with the potential to challenge and thus to deterritorialize and/or reterritorialize their 'life' stories and hence their 'lives'. Thus the paradox of the refrain, of these habits, is "the possibility of both rupture and sameness, in other words, difference and repetition" (Mazzei 2016, 151). And in this particular place at this particular time it repeats. For the place may have changed, deterritorialized (Deleuze and Guattari 1987, 3), its doors storified to admit a few of those previously excluded (the female, the coloured) but this refrain, striated and sedimented, acts to reterritorialize, recolonize, and restorify the 'guest' as 'unwelcome guest' with management-predominantly white Anglo male with one sole token coloured woman administrator appointed (Frank 2012, 2000; see also Fricker 2012)-the keepers of and at the 'gate'. You might be allowed in but terms and conditions apply.

\section{Power as in-formation}

Such schools often posit that their practices are inclusive of all, different and alike. Such a pedagogy/ideology of supposed "colorblindness" (Schofield 2007; see also Aragón, Dovidio and Graham 2016, 2) where all are said to be seen as equal with difference not acknowledged at all although seemingly quite progressive is rather part of "flexible and malleable neoliberal assemblages" (Pacini-Ketchabaw, Nxumalo and Rowan 2014, 39) which by virtue of their covertness are much more divisive, exclusionary and potentially destructive than an overt pedagogy/ideology of apartheid where difference is seen as 'other', with the 'other' subordinated and subordinate to what is considered the sociopolitical and discursive 'norm', excluded yet not indifferent to their very difference. For by ignoring difference/diversity, what is different and valued by 'others', "'in-forms'" (Massumi in conversation with Mary Zournazi 2002, 224) the 'other'-forms them, colonializes them, from the inside out to see difference as less than, shameful and valueless. Such internal colonialization means that the 'other' others themselves with no need for the dominant's ethical condemnation (Leder 1996) and is a colonialization, a conditioning, that forms and sediments "the fascist inside you, the fascist you yourself sustain and nourish and cherish" (Deleuze and Guattari 1987, 215) to perpetuate the status quo. It is what Massumi (Massumi in conversation with Mary Zournazi 2002, 224) following Foucault calls "power to" rather than "power over": 
Power comes up with us from the field of potential. It 'informs' us, it's intrinsic to our formation, it's part of our emergence as individuals, and it emerges with us-we actualise it, as it in-forms us. So in a way it's as potentialising as what we call freedom, only what it potentialises is limited to a number of predictable paths. It's the calculable part of affect, the most probable next steps and eventual outcomes. (Massumi in conversation with Mary Zournazi 2002, 224)

As Foucault ([1980] 2000, 275) reminds us: power produces rather than represses, regularizes rather than diversifies. And to produce a subject power requires "the destruction of what we are as well as the creation of a completely different thing, a total innovation."

\section{Some final thoughts}

Hospitality as productive power, one that resists the gravitational pull of Western doxa, is about understanding that commitments to diversity that do not bring about that which is promised are best understood as non-performative (Ahmed 2012). The all-too-often use of student demographics to demonstrate and celebrate diversity and equality as something already accomplished is however a clever (though dishonest) strategy that obscures the reality within, creating the fantasy that discrimination is indeed 'over' and a thing of the past. The creation of documentation attesting to diversity and equality in and of itself confirms this to be a matter of fact in the minds of the institution. Nothing could be further from the 'truth'. And so it falls to the stranger within to perturb this fantasy, perturb possibilities of acting other and 'other'. The fact that the stranger is already within ensures that the 'danger' posed is one of political "auto-immunity" (Derrida 1998, 2003), a challenge at once ontological as it is ethical and epistemological, with the institutional body politic under attack by its very self: a deconstruction of the self by the self. For storying and storytelling are deeply performative, physical experiences, intra-relational and more often than not shared. In this respect they are "virtual social imaginaries as much as (...) autobiographical reports on actual events" (Andrews and Duff 2019, 129). And they create places of opportunity: placed yet placeless places-concrete and territorial yet a part of the social imaginary-where difference abides and governance, policy, and administration no longer trace lives. These are places of opportunity that allow African notions of hospitality, that which underpins the southern African 'philosophy' of Hunhu/Ubuntu, to be neither consumed nor compromised in an effort to work against the normalizing tendency of schools to privilege presence over absence, Western ways of knowing, being and doing over an entirely different material reality.

In linking the Zulu/isiNdebele word Ubuntu with its Shona equivalent Hunhu, the South African Ubuntu scholar and philosopher Mogobe Bernard Ramose entwines the notion of $\mathrm{Hu}-$ and Ubu-, that of being, with that of -ntu and -nhu: knowing: the ontological with the epistemological (Ramose 1999, 50): knowing in being. Both words (Hunhu/Ubuntu) also speak to the character of a person, their conduct and as such also entwines the ethical with the ontological with the epistemological. As such the Western conception of Ubuntu that views it as an anthropocentric philosophy could not be more misguided as it is at once philosophy and praxis, a philosophical practice and practical philosophy that sees humanity as part of the never-ending unfolding of life forces and knowledge within 
a "dynamic, relational, and necessarily uncertain/unknowable future" (Wu, Eaton, Robinson-Morris, Wallace, and Han 2018, 11). From an African perspective one's being is always relational, always informed and formed through an active engagement with the cosmos in its entirety (Wu, Eaton, Robinson-Morris, Wallace, and Han 2018), colonizers included. And to ignore this is to negate the very humanity which binds us all together to the world in all its materialdiscursive entirety (Ramose 1999).

To "move beyond the conditional acceptance of difference is at the heart of the ethics of hospitality" Deumert and Mabandla $(2017,404)$ state and to allow difference to interconnect and merge for the sake of exchange, "to facilitate interdependence" (Rose 2002, 314) vital if we are to decolonialize the places where the colonial refrain remains the same: intact. For it is only in so doing that the refrain will effect the "holding together of heterogeneous elements" (Deleuze and Guattari 1987, 323) that allows for deterritorialization to fold and unfold. And it is only under such conditions, where the 'other' can tell their stories in their own ways dispelling myths of inferiority (MaldonadoTorres 2017, 130), that place and inhabitant become "a-grammatical and asignifying"(MacLure 2016, 173), a "potential threat to order" (MacLure 2016, 175) that can cause the colonizers' stories to stutter, to make false starts, to pause (MacLure 2016, 176), to facilitate what Deleuze and Guattari (1987) call "rhizomatic" assemblages to manifest, an "embodied flow of pauses and rushes" (Hickey-Moody 2013, 278) to emerge and make decoloniality, currently virtual-potentiality-in-the-making, a reality.

\section{References}

Ahmed, Sarah. 2000. Strange Encounters. Embodied Others in Post-coloniality. London: Routledge.

-. 2004. The Cultural Politics of Emotion. Edinburgh: Edinburgh University Press.

-. 2012. On Being Included: Racism and Diversity in Institutional Life. Durham/London: Duke University Press.

Andrews, Gavin J., and Cameron Duff. 2019. Matter Beginning to Matter: On the Posthumanist Understandings of Vital Emergence of Health. Social Science \& Medicine, 226: 123-234.

Anzaldúa, Gloria. 1987. Borderlands/La frontera: The New Mestiza. San Francisco, CA: Aunt Lute Book Company.

Aragón, Oriana R., John F. Dovidio, and Mark J. Graham. 2016. "Colorblind and Multicultural Ideologies are Associated with Faculty Adoption of Inclusive Teaching Practices." Journal of Diversity in Higher Education. Advance online publication. http://dx.doi.org/10.1037/dhe0000026

Barad, Karen. 2007. Meeting the Universe Halfway: Quantum Physics and the Entanglement of Matter and Meaning. Durham, NC: Duke University Press. 
Cohen, Jeffrey J. 2015.Stories of Stone: An Inhuman Ecology. Minnesota: University of Minnesota Press.

Collins-Gearing, Brooke, and Dianne Osland. 2010. "Who will Save us from the Rabbits?: Rewriting the Past Allegorically." The Looking Glass 14 (2). Retrieved from http://www.lib.latrobe.edu.au/ojs/index.php/tlg/article/view/227/225

Deleuze, Giles, and Felix Guattari. 1987. A Thousand Plateaus. Minneapolis: University of Minnesota Press.

Derrida, Jacques. 1998. Faith and Knowledge: The Two Sources of 'Religion' at the Limits of Reason Alone, translated by S. Weber. In Religion edited by G. Vattimo \& Jacques Derrida: 1-78. Stanford, CA: Stanford University Press.

Derrida, Jacques. 2003. Autoimmunity: Real and Symbolic Suicides. In Philosophy in a Time of Terror: Dialogues with Jürgen Habermas \& Jacques Derrida, edited by G. Borradori: 85-136). Chicago: The University of Chicago Press.

Derrida, Jacques. 2005. "The Principle of Hospitality". Parallax 11: 6-9. doi: $10.1080 / 1353464052000321056$

Derrida, Jacques, and Anne Dufourmantelle. 2000. Of Hospitality: Anne Dufourmantelle invites Jacques Derrida to Respond: Cultural Memory in the Present edited by Mieke Bal and Hent de Vries. Translated by Rachel Bowlby. Stanford: Stanford University Press.

Deumert, Ana, and Nukululeko Mabandla. 2017. "A Luta Continua - Black Queer Visibilities, Philosophies of Hospitality and the Decolonization of Everyday Life in a South African Rural Town." Journal of Sociolinguistics 21: 397-419. doi: $10.1111 /$ josl.12238

Foucault, Michel. (1980) 2000. Interview with Michel Foucault, interviewed by D. Trombadori, and translated by Robert Hurley. In Michel Foucault: Power. The essential works of Michel Foucault 1954-1984: Volume III, series edited by Paul Rabinow and volume edited by J. D. Faubion: 239-297. New York: The New Press.

Frank, Arthur W. 2000, "Illness and Autobiographical Work: Dialogue as Narrative Destabilization". Qualitative Sociology 23 (1): 135-156.

-. 2010. Letting Stories Breathe: A Socio-narratology. Chicago: The University of Chicago Press.

-. 2012. "Practicing Dialogical Narrative Analysis." In Varieties of Narrative Analysis edited by J. A. Holstein and J. F. Gubrium 33-52. Los Angeles: Sage.

Fricker, Miranda. 2007. Epistemic Injustice: Power and the Ethics of Knowing. Oxford: Oxford University Press. 
-. 2012. "Silence and Institutional Prejudice." In Out from the shadows: Analytical feminist contributions to traditional philosophy edited by S. L. Crasnow and A. M. Superson: 287-306. Oxford: Oxford University Press.

Gruenewald, David A. 2003. "Foundations of Place: A Multi-disciplinary Framework for Place-conscious Education." American Educational Research Journal 40 (3): 619654.

Haraway, Donna. 1988. "Situated Knowledges: The Science Question in Feminism and the Privilege of Partial Perspective." Feminist Studies 14 (3): 575-599.

Hickey-Moody Anna C. 2013. "Deleuze's Children." Educational Philosophy and Theory 45: 272-286.

Iovino, Serenella, and Serpil Oppermann. 2014. "Introduction: Stories come to matter." In Material Ecocriticism edited by Serenella lovino and Serpil Oppermann: 1-17. Bloomington: Indiana University Press.

Janz, Bruce B. 2001. "The Territory is Not the Map: Place, Deleuze and Guattari, and African Philosophy." Philosophy Today, Winter: 393-404.

Kristeva, Julia. 1991. Strangers to Ourselves. translated by Leon S. Roudiez. New York: Columbia University Press.

Leder, Drew. 1990. The Absent Body. Chicago, IL: Chicago University Press.

MacLure, Maggie. 2013. "The Wonder of Data." Cultural Studies $\leftrightarrow$ Critical Methodologies 13(4): 228-232. doi: 10.1177/1532708613487863

MacLure, Maggie. 2016. "The Refrain of the A-grammatical Child: Finding Another Language in/for Qualitative Research." Cultural Studies $\leftrightarrow$ Critical Methodologies 16(2): 173-182. doi: 10.1177/1532708616639333

Maldonado-Torres, Nelson. 2007. "On the Coloniality of Being: Contributions to the Development of a Concept." Cultural Studies, 21 (2-3): 240-270.

Maldonado-Torres, Nelson. 2017. On the Coloniality of Human Rights. Revista Crítica de Ciências Sociais, 114: 117-136.

Mazzei, Lisa A. 2016. "Voice without a Subject." Cultural Studies $\leftrightarrow$ Critical Methodologies 16 (2): 151-161. doi: 10.1177/1532708616636893

Mignolo, Walter. 2017, Jan. 21. Interview-Walter Mignolo/Part 2 Key Concepts. Retrieved from https://www.e-ir.info/2017/01/21/interview-walter-mignolopart-2-keyconcepts/ 
Pacini-Ketchabaw, Veronica, Fikile Nxumalo, and Mary C. Rowan. 2014. "Researching Neoliberal and Neocolonial Assemblages in Early Childhood Education." International Review of Qualitative Research 7 (1): 39-57.

Patton, Paul. 2000. Deleuze and the Political. New York, NY: Routledge.

Ramose, Mogobe B. 1999. African Philosophy Through Ubuntu. Mond Books

Richardson, Laurel. 1997. "Skirting a Pleated Text: De-disciplining an Academic Life." Qualitative Inquiry 3 (3): 295-303. doi:10.1177/107780049700300303

Rose, Deborah B. 2002. "Dialogue with Place: Toward an Ecological Body." Journal of Narrative Theory 32 (3): 31 1-325.

Slaby, Jan, Rainer Mühlhoff, and Philipp Wüschner. 2017. "Affective Arrangements." Emotion Review: 1-10. doi: 10.1177/1754073917722214

Schofield, Janet W. 2007. The Colorblind Perspective in School: Causes and Consequences. New York, NY: Wiley.

Spry, Tami. 2001. "Performing Autoethnography: An Embodied Methodological Praxis." Qualitative Inquiry 7 (6): 706-732.

St Pierre, Elizabeth A. 1997. "Methodology in the Fold and the Irruption of Transgressive Data." Qualitative Studies in Education 10 (2): 175-189.

Wu, Jinting, Paul William Eaton, David W. Robinson-Morris, Maria F. G. Wallace, and Shaofie Han. 2018. Perturbing Possibilities in the Postqualitative Turn: Lessons from Taoism and Ubuntu. International Journal of Qualitative Studies in Education. doi:10.1080/09518398.2017.1422289

Zournazi, Mary. 2002. "Navigating movements - with Brian Massumi." In Hope: New Philosophies for Change by Mary Zournazi: 210-243. Annandale, Sydney: Pluto Australia. 